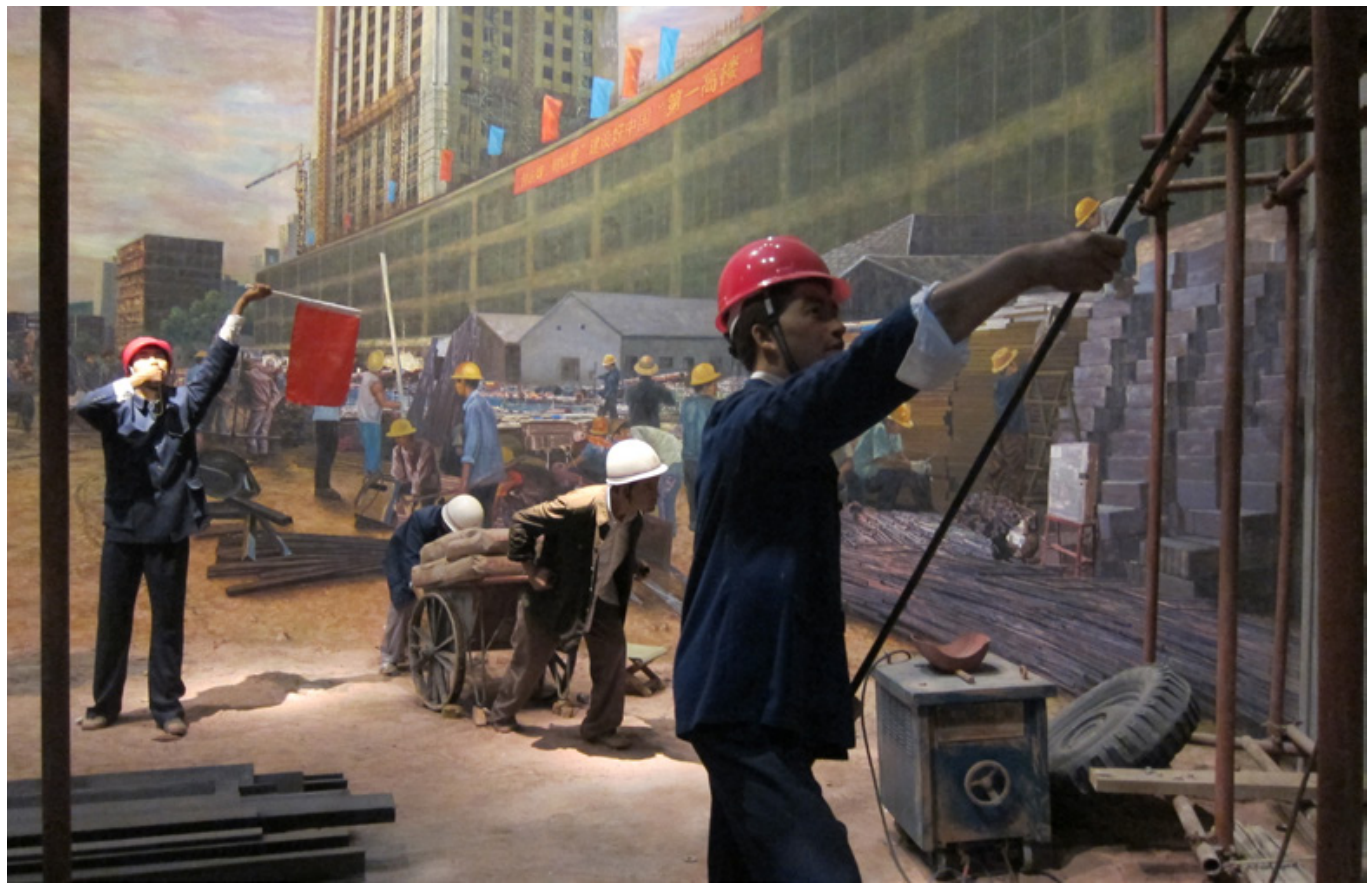

\section{What Kind of Model? \\ Thinking about the Special Economic Zone and the Socialisty City}

Jonathan BACH

This essay asks whether the special economic zone could, counterintuitively perhaps, reflect the morphology of the socialist city. By locating the roots of today's special economic zones in socialist urbanism, this essay both complements and questions the standard genealogy of the zone in capitalism and our imagination of global infrastructural space.
Building Shenzhen. Diorama at the Shenzhen Museum, 2015. PC: Jonathan Bach. ooking through the lens of the economic zone seems eminently fruitful for conceptualising the infrastructural logic of socio-spatial transformation that has been the result of China's economic growth in the last 40 years. Since China embraced and adapted the zone model as a site for production of exports and accumulation of capital in the 1980s, it has paved the way the way for the economic zone to develop into an urban form(ula). This new urban typology has infrastructure at its core-from the 'hard' infrastructure of ports and pipes, roads and 
factories, and electronic 'backbones' to 'softer' infrastructures of housing, entertainment, education, and 'creative' spaces to nurture and attract the right 'talent'. Zone cities have a uniform appearance, often drawing on a handful of international consulting companies, architecture and construction firms, and retail complexes-not to mention the firms doing the investment. As I have argued (2011), and as Keller Easterling (2014) has explored, these new urban forms constitute a spatial formation of late modernity, one where socio-technical infrastructures graft onto, transplant, and extend existing ideas about cities as catalysts for global structural transformation. As a worldwide phenomenon, the infrastructural space of zones has become part of the geographical imagination of the global economy.

Nowhere in recent decades has the rise of the special economic zone as a type of infrastructural technology been as prominent as in China, which has turned its own experience with special economic zones (foremost among them Shenzhen) into an export model of its own. Yet most of the discussion around contemporary zones centres on their role as parvenus of capitalist globalisation, whether from the perspective of the enthusiast or the critic. In this brief essay I would like to compliment the standard genealogy of the zone in capitalism by raising a different set of questions about whether the zone can be seen as part of the morphology of the socialist city itself. Can the zone be a fruitful empirical site for exploring, not only the capitalist contours of contemporary production and consumption, but the genealogy of socialist urban planning, its hybrid legacy today, and its transformation under neoliberal economic forces? Can looking at the zone as a type of hybrid socialist legacy raise questions about varieties of socialism in practice, especially the Asian developmental state, and thus be useful for thinking about the new zonal logics of China's global infrastructural network?

\section{Socialist Meta-Models}

In the introduction to our recent volume on the Chinese post-Mao model city of Shenzhen (O'Donnell, Wong, and Bach 2017), my coauthors and I called attention to how the city's delirious rise is premised on earlier socialist models, such as the famous agricultural commune in Dazhai or the industrial iron man spirit' of the city of Daqing, which the entire country was to 'learn from' in order to, as the slogan went, 'surpass England and catch up with the United States' (to these we could have added the city of Panzhihua and other Third Front experiments). These cases share the defining impulse of modernist cities to start anew, afresh, and from a blank slate. This idea of the tabula rasa 'new city' has a long history-Descartes himself evoked the planned city as encompassing the privileged qualities of method, rationality, and objectivity. Descartes' ideal city, noted the historian Matt Erlin (2004, 3 ), 'is essentially ahistorical, the eternally valid construct of a single, unified, rational subjectivity'.

Socialist cities famously embraced the idea of urban planning as a fresh start for institutionalising new universal subjectivities and rationalities. As Kimberly Zarecor (2018, 5) concedes, 'all socialist cities were modernist, but not all modernist cities were socialist,' and yet, she argues, the way in which the modernist quality was adopted in socialist settings contributed significantly to socialist urban forms and their legacies. The logic of the socialist 'model', I submit, is central to understanding socialist urban forms, and to seeing the zone as one of its prominent legacies.

There are arguably three basic dimensions of the socialist (meta) model for model making. The first and foremost is the ontological commitment to state-led development. For various well-known reasons, socialist countries sought solutions through the heavy hand of the state as opposed to market-driven approaches to development. This was hardly restricted to the Soviet or Marxist model, since it can also describe, with variations, the post-war Asian 
developmental model of countries such as Japan and South Korea, and the Scandinavian model.

The second is the concept of the test space. The state-led project often starts with a chosen village, city, commune, or other space that is selected as the site for an experiment. The site of the experiment, more often than not, was in an area where risks could be controlled. In China, sites for early experiments with market reforms often took place in rural settings (e.g. Town and Village Enterprises). The first special economic zones were placed not in existing economic centres such as Shanghai or Tianjin, but in reasonably remote areas such as Shenzhen, Xiamen, and Hainan, where failure could be more easily contained (there were additional strategic reasons for choosing these locations, of course, including their proximity to overseas Chinese capital in Hong Kong and Taiwan). But more important than containing possible failure was the advantage that experimental spaces allowed for trying out new policies and plans. Paying attention to the early period of experimentation in such spaces can tell us much about subsequent events and processes.

The third is the transformation of society, what Zarecor (2018) has identified as 'infrastructural thinking' in the service of 'total societal transformation' by connecting material production with social transformation. These state-chosen experimental spaces achieve their transformative goals not through local impact, but through emulation. The test spaces must therefore become both symbolically and materially portable. If successful, the experiment would be emulated and expanded until it became the norm. Emulation can take the form of highly visible campaigns exhorting citizens to 'learn from X or Y', new construction techniques or materials, new policy guidelines or technology transfer. While many historical models were made to be as visible as possible, the logic could also encompass less visible forms, such as Soviet 'secret' cities designed for weapons and other forms of industrial production. These secret cities both drew from, and in a sense perfected, the idea of the 'model' city.

\section{The Special Economic Zone as a Model}

These three characteristics came together in my and my colleagues' work on the city of Shenzhen, which prompted me to think about the connection between socialist-era 'model' cities, and model making and socialist/postsocialist special economic zones. It is well known that special economic zones, themselves a variation on earlier export processing zones, became a major phenomenon of the global economy in the 1980s across the Global South, notably in China. While most of the literature on zones discusses them in the context of capitalist development from a macro-economic perspective (e.g. evaluating the amount of foreign direct investment they attract), the socialist and post-socialist world continues to play an understudied but significant role in their historical trajectory.

While the spread of special economic zones is often regarded as part of the story of capitalist triumph after the end of the Cold War, their rise as a hybrid socialist/capitalist model city in China took place a decade before the collapse of the Soviet Union, Vietnam has been exploring special economic zones since the early 1990s, and North Korea continues to experiment with them. Russia, in its postSoviet incarnation, has embraced the idea with 18 of its own special economic zones, while former Soviet republics have pursued them as well (with mixed results). Thus, while at first glance the phenomenon of the special economic zone seems diametrically opposed to socialism (e.g. when zones claim to represent the 'freest' market principles, including weak regulation and taxation and easy repatriation of profits to companies), they arguably exhibit a similar logic to some socialist urban 


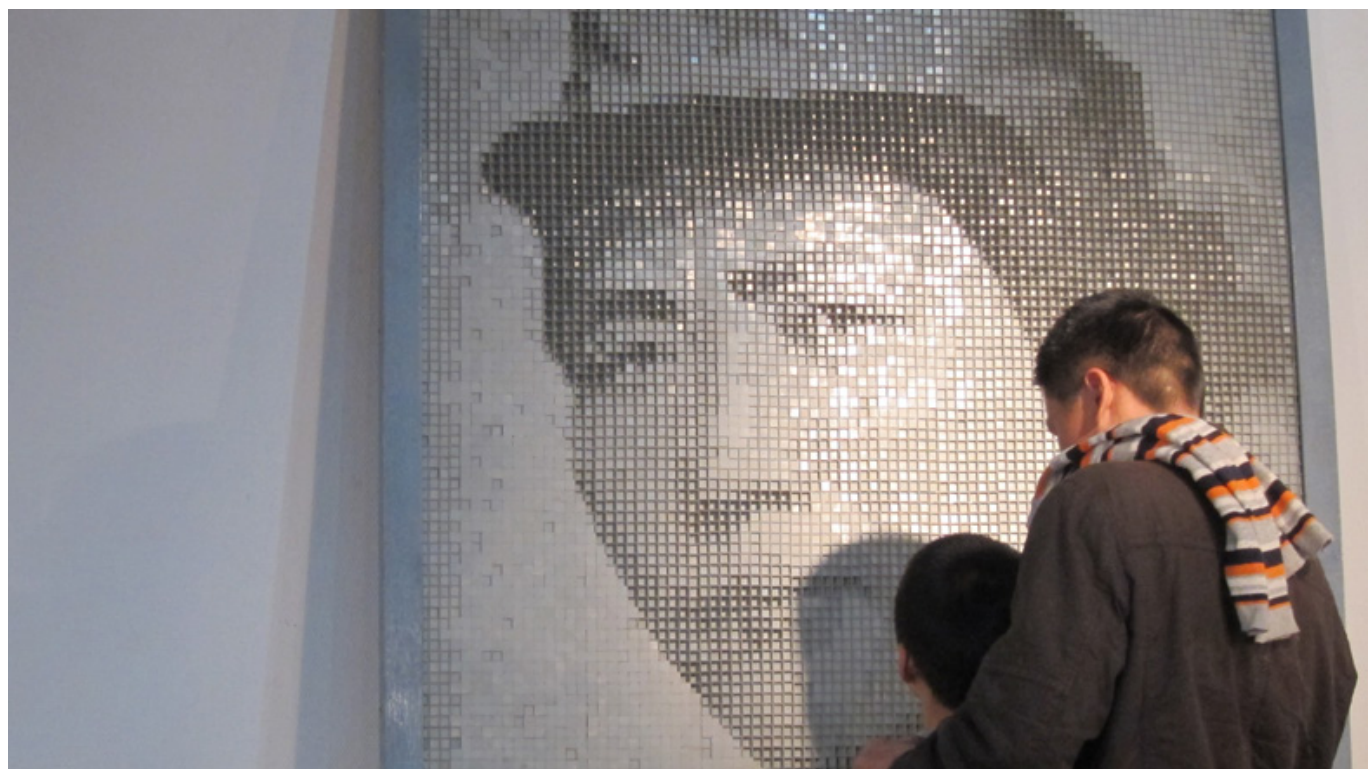

Scene at an exhibit (F518 Art Space),

Shenzhen, China, 2015

PC: Jonathan Bach.

models in their genesis as state-led projects of experimentation, transformation, and emulation.

As with socialist planned urban spaces from Marzahn to Magnitogorsk, the zone requires complete legal and spatial control by the state over the territory. More often than not, the zone is explicitly tied to a project of 'total societal transformation'. That this transformation takes a neoliberal, rather than classic socialist form, does not alter its claim to be able to fundamentally reshape and revolutionise society (and in China the claim is still that this transformation is with the ultimate goal of realising socialism). Zones are invoked as part of plans to lead the country in the direction of future harmonious prosperity or, as the World Economic Processing Zone Association puts it, 'to lead both poor and rich countries to their wealthier destinies' (Bolin 2014). Thus, because they are intimately connected to national aspirations of industrialisation, zones become an experimental space in which new forms of production, living, working, and being are enacted which, if successful, will be expanded to the rest of the country. If from an economic point of view zones exist to export products, from a political point of view they exist to transform societies.

Let me give two brief examples of the social transformative dimensions of zones, from both the (nominally) capitalist and socialist worlds. China's Shenzhen Special Economic Zone, formally established in 1980, was the cornerstone of a massive economic and social experiment to create a post-Mao society by developing 'material and spiritual civilisation' (物质文明与精神文明). For the material side of the equation, exports and foreign direct investments were key, but for the spiritual side, new subjectivities were needed. What came to be called 'Shenzhen Spirit' (深圳精神) became the method to create the new form of worker for the post-Mao era. As Eric Florence (2017) has shown, this new worker must simultaneously 'sacrifice themselves and their whole lives' to 


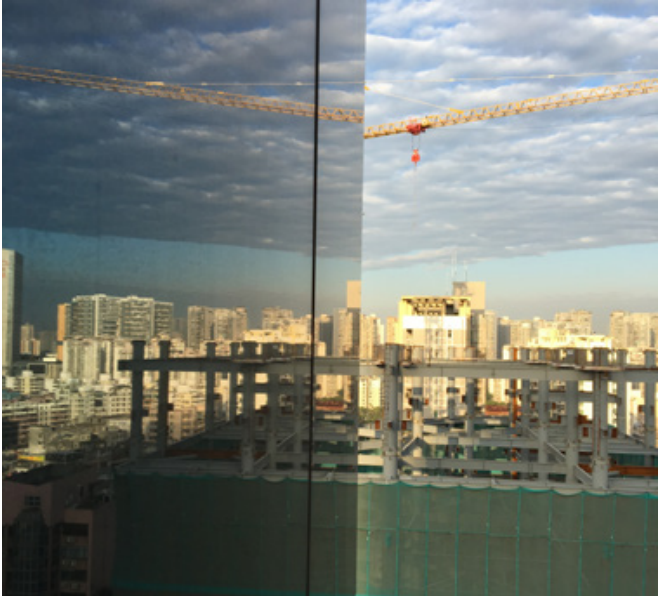

the nation while building a spiritual civilisation by 'deciding for oneself, strengthening oneself, autonomy, competition, taking risks and facing danger, equity, effectiveness, and legality', according to an official list of values from the city's Communist Party, while Shenzhen Spirit, in turn, should contribute to the 'four-have new person' who should have 'ideals, culture, virtue, and discipline' (cited by Florence 2017, 87).

The zone model, with its new worker subjectivity and spirit, was thus meant to transform the entire country, and it did. In 1980, there were four new Special Economic Zones in China. Today, nearly every city in China has a variation of a zone existing to attract foreign investment and shape the modern citizen. Not every city can become Shenzhen (which went from a rural area with villages and market towns to a metropolis of over 20 million people in one generation), but Shenzhen serves as both a national and now global model-from India (e.g. a headline in the Times of India in 2015: 'UP to be developed into China's Shenzhen Model') to what Deborah Bräutigam and Tang Xiaoyang (2011) have called 'African Shenzhen' in China's export of the zone model.

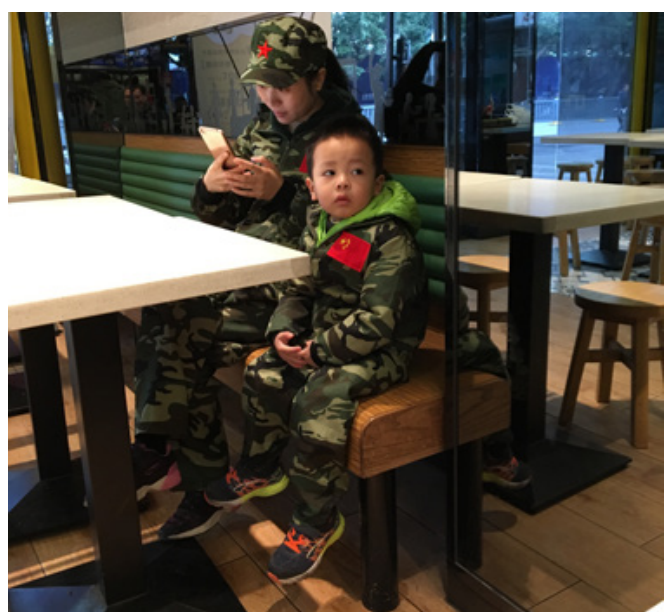

(Left) City view, Nanshan, Shenzhen; (Right) In a cafè, Nanshan, Shenzhen. PC: Jonathan Bach.

In South Korea, despite the different circumstances, a similar logic was at work. As Bae-Gyoon Park (2005) has shown, when the country reintroduced special economic zones in the early 2000s, it was no longer to create an export-driven economy (as in the 1970s and 1980s), but to create spaces where 'liberalisation' could be introduced and, if successful, slowly expanded to the rest of the country. Here the zone was seen as a way to undermine the power of protectionist chaebols (large firms such as Samsung), bureaucrats, and labour unions. While, again, the economic goals may be opposite to socialism, the larger goal is that, as Bridget Martin (2013) writes, 'people will become fully incorporated into a property system, a social life, and an economic order over which they have less and less control', noting how villages on the site of zones were replaced by 'a planned arrangement of infrastructure falling into the sanctioned categories of "housing", "shopping centers", "office space", "church", and "school".

The zone is thus a recognisable strategy or scaffolding-in Zarecor's (2018) sense-that 'activates' discrete, state-controlled urbanised space by seeking to marry social transformation with material production. Zones are a tabula 
rasa approach to planning which, among other things, avoids the messiness of dealing with existing urban centres. Both the zone-as-city and zone-as-appendage allow the state to approach urban space as the proverbial 'blank slate'. What Eli Rubin (2016) wrote about how the East Berlin satellite city of Marzahn appeared as a form of 'amnesiopolis', a place with no past but only futures, is also a hallmark of the zones. The Shenzhen municipal government, as I discussed elsewhere (2016), sought to physically and discursively erase the traces of its villages and successfully promote the narrative that the city's history began effectively in 1980 . The zone as a city provides the tantalising promise of an eternal 'fresh start' unencumbered by baggage of the past and resolutely facing the future. As a consultant proudly pronounced to Bridget Martin (2013) as she was doing her research on the South Korean zone of New Songdo City: 'It's not an experiment, it's the future!'

\section{China and the Legacies of the Socialist City}

China arguably plays a key role for the continuity of socialist cities into the present day, especially as they turn their cities into global models. What is often overlooked in the literature on zones and Chinese cities is how Chinese urban space draws directly on the multiple influences of Soviet urban planning, Chinese socialist planning (especially the idea of the work unit, or danwei) and Asian developmental models. Their original special economic zones certainly closely reflected lessons from the export model of the 'Four Tigers' (South Korea, Taiwan, Hong Kong, and, above all, Singapore). Yet the practices of planning the new zones drew on generations of planners, architects, policymakers, and residents whose point of urban reference was Soviet-style planning. As Jacob Dryer (2014) writes about Soviet influence in Chinese urban development, 'the Soviet model city could be realized on Chinese soil, when it could not be in Russia, because there were fewer impediments ... Soviet architectural typologies and the models of Soviet urban planners constituted the first vision of cities ever glimpsed by Chinese peasants in a rapidly modernizing society.'

Can we see in the rapid spread of economic zones worldwide the traces of socialist cities? If so, what would it mean for our understanding of both the genealogy of socialist planning and the function of zones today? For true believers of neoliberal dogma, the zone serves as a catalyst for a harmonious future, yet as with the lived reality under socialism, many zones are hollow promises, with unfinished infrastructure and 'ghost cities' of uninhabited high rises serving as visual markers of corruption, vanity projects, and plans gone astray. At the same time, zones have become a fundamental form of urban development in much of the world. Might an understanding of socialist model making help us understand this phenomenon?

In Andrei Tarkovsky's famous film Stalker, the Zone is the only open space left capable of transformation and possibility, a dangerous place with an irresistible mythical room at its core that can fulfil dreams. When the film came out in 1979, China was preparing to announce its first special economic zones and thereby transform both socialist and capitalist development. As national spaces of exception, zones are like secret rooms that promise to fulfil the dreams of countries. As part of the geographic imagination of capital, they form a parallel world parasitic on, but separate from, sovereign states. And with their traces of socialist practices and planning, they might also tell us something about the past and future of the socialist city. 